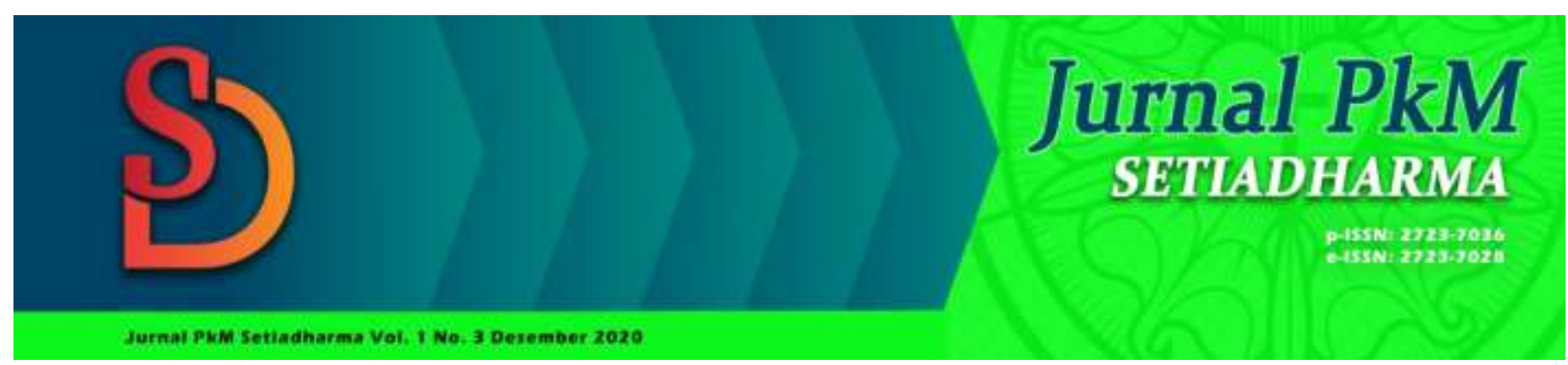

\title{
PROGRAM SMK (SAYA MURID KRISTUS) SEBAGAI PENDEKATAN YANG MENGUATKAN PANGGILAN DALAM AMANAT AGUNG DI GBI BETHEL BANDUNG
}

\author{
Yahya Fajar Edhi Nugroho, ${ }^{1}$ Yanto Paulus Hermanto, ${ }^{2}$ Rubin Adi Abraham $^{3}$ \\ Sekolah Tinggi Teologi Kharisma Bandung \\ sttkyahya19@gmail.com,yantopaulush@gmail.com,rubinabraham2@gmail.com
}

Sekolah Tinggi Teologi Kharisma Bandung

Diterima:
08-12-2020
Direvisi:
16-12-2020
Diterbitkan:
29-12-2020
Keywords: Great
Commission,
Discipleship,
Covid-19
Pandemic
Pandemi Covid-19
Kata Kunci:
Pemanat Agung,
Pandan,
Pande

\begin{abstract}
In the realization of the implementation of the Great Commission of Christ, the church apart from preaching or evangelizing, the church also performs discipleship or is often referred to as teaching new souls and their congregations. A church that has experienced the benefits of the disciplenship process will surely grow in the spiritual quality of its congregation. The effect of the benefits that can be seen is that someone who has followed the process of discipleship, that person will certainly grow his spiritual life towards spiritual maturity. Spiritual maturity is very important for believers so that their lives truly reflect the character of Christ. Christians who have reached the spiritual maturity stage will have a strong and solid faith amidst the onslaught of the influence of misleading teachings (false gospels) and amidst the challenges of the storms of lifeduring the covid-19 pandemic and have a heart's desire to serve God with love faithful so that many new souls are brought to Christ. Through this paper, the author will invite readers to find out what effective steps for discipleship will be during the covid-19 pandemic?
\end{abstract}

\begin{abstract}
Abstrak
Dalam perwujudan pelaksanaan Amanat Agung Kristus gereja selain melakukan pewartaan atau penginjilan, gereja juga melakukan pemuridan atau sering disebut dengan pengajaran kepada jiwa-jiwa baru dan jemaatnya. Gereja yang sudah mengalami manfaat dari proses pemuridan pasti gereja tersebut bertumbuh secara kualitas kerohanian jemaatnya. Dampak manfaat yang dapat dilihat adalah bahwa seseorang yang telah mengikuti proses pemuridan, orang tersebut pasti bertumbuh kehidupan rohaninya menuju kepada kedewasaan rohani. Kedewasaan rohani sangat penting bagi orang percaya agar kehidupan mereka sungguh nyata mencerminkan karakter Kristus. Orang Kristen yang sudah mencapai tahap dewasa rohani akan memiliki iman yang kuat dan kokoh di tengah gencarnya serangan pengaruh pengajaran yang menyesatkan (injil palsu) dan di tengah berbagai tantangan badai kehidupan di masa pandemi Covid-19 ini dan memiliki kerinduan hati untuk melayani Tuhan dengan kasih setia sehingga banyak jiwa-jiwa baru yang dibawa kepada Kristus. Lewat tulisan ini penulis akan mengajak pembaca untuk mengetahui langkah efektif pemuridan yang seperti apa di masa pandemi Covid-19 ini?
\end{abstract}

\footnotetext{
${ }^{1}$ Mahasiswa Program Magister Teologi Sekolah Tinggi Teologi Kharisma Bandung

${ }^{2}$ Dosen Prodi Karya Tulis Ilmiah Program Magister Teologi Sekolah Tinggi Teologi Kharisma Bandung

${ }^{3}$ Dosen Program Magister Teologi dan Rektor Sekolah Tinggi Teologi Kharisma Bandung
} 


\section{PENDAHULUAN}

"Awal tahun 2020 ditandai dengan satu peristiwa yang mengejutkan seluruh dunia. Virus Corona berkembang mulai dari propinsi Wuhan, China sejak akhir 2019, secara masif mulai menyebar ke berbagai negara di dunia, menjadi sebuah pandemi yang disebut COVID19 (Corona Virus Disease 2019)."“ Dunia saat ini sedang diguncang oleh pandemi Covid-19. Berita yang muncul di media informasi baik secara media cetak (majalah dan surat kabar), media elektronik (televisi dan radio, koran digital) dan sosial media (facebook, instagram dan youtube) menyiarkan wabah penyakit Covid-19 sejak bulan Desember 2019 sampai dengan tulisan ini ditulis.

Dampak dari wabah penyakit ini menyebabkan ekonomi terguncang dan ada negara yang sampai mengalami resesi. CNBC Indonesia menuliskan. "Singapura mengalami Resesi, negara lainnya seperti Jepang dan Jerman juga." ${ }^{5}$ Terjadi pemutusan hubungan kerja di berbagai sektor industri non pangan dan non farmasi, hal ini disebabkan produksi menurun, ekspor menurun dan konsumsi daya beli masyarakat melemah, pusat pembelanjaan sepi (mall, supermarket, pasar modern dan pasar tradisional sepi pembeli) dan tempat wisata sepi dikarenakan adanya pembatasan jam buka untuk pengunjung dan pembatasan pembeli, bahkan ada yang sampai ditutup pada saat berlangsungnya PSBB (Pembatasan Sosial Berskala Besar) di kota-kota besar di Indonesia seperti Jakarta, Bandung, Yogyakarta, Surabaya, Semarang, Palembang, Makasar, dan Medan. Surat kabar elektronik Kompas.com menulis dalam judul artikelnya, "Dampak Corona, Jumlah Pengangguran Semakin Bertambah Tembus 12,7 Juta di 2021."6 "Dampak pandemi Covid-19 ini selain menyebabkan ekonomi terpuruk, ${ }^{7}$ juga berdampak pada sektor pendidikan, ${ }^{8}$ politik ${ }^{9}$ dan spiritual kerohanian umat manusia." Sudah hampir tujuh bulan (sejak bulan April sampai dengan bulan Oktober 2020) tempat ibadah berbagai agama di Indonesia termasuk gereja ditutup oleh pemerintah, masyarakat dilarang sementara untuk tidak melakukan aktivitas keagamaan, untuk menghindari kerumunan masal dan mencegah/memutus rantai penyebaran wabah penyakit Covid-19.

Masyarakat Indonesia dan dunia saat ini membutuhkan kabar baik, kabar yang membangkitkan semangat dan pengharapan akan adanya pemulihan ekonomi, sosial dan spiritual kerohanian. Sebagian besar orang percaya secara psikologis juga mengalami dampak dari pandemi ini dan tidak sedikit orang percaya yang mulai meninggalkan Tuhan, sebab orang Kristen yang tidak memiliki pondasi iman yang kokoh, sangat mudah sekali tergoncang imannya lewat situasi sulit tekanan hidup dan sangat mudah sekali mundur dari Tuhan. Oleh sebab itu sangat diperlukan sekali adanya bimbingan spiritual/pendalaman tentang kebenaran firman Tuhan yang ada di Alkitab oleh gereja/hamba Tuhan yang kuat imannya kepada orang Kristen petobat baru, sebagai wujud pelaksanaan salah satu tugas orang Kristen dalam Amanat Agung Kristus untuk memuridkan/didaskalia (Mat. 28:18-20), "Yesus mendekati mereka dan berkata: ". . Karena itu pergilah, jadikanlah semua bangsa murid-Ku dan baptislah mereka dalam nama Bapa dan Anak dan Roh Kudus, dan ajarlah mereka melakukan segala sesuatu yang telah Kuperintahkan kepadamu." Pemuridan merupakan mandat agung dari Kristus.

\footnotetext{
${ }^{4}$ David Alinurdin, 'COVID-19 Dan Tumit Achilles Iman Kristen', Veritas: Jurnal Teologi Dan Pelayanan, 2020 <https://doi.org/10.36421/veritas.v19i1.373>.

${ }^{5}$ Reihan Sebayang, 'Singapura Resesi, Jerman Dan Jepang Juga', Cnbcindonesia (Jakarta, 2020).

${ }^{6}$ Mutia Faiza, 'Dampak Corona, Jumlah Pengangguran Bisa Tembus 12,7 Juta Di 2021', Kompas.Com (Jakarta, 2020).

${ }^{7}$ Dito Aditia Darma Nasution, Erlina Erlina, and Iskandar Muda, 'Dampak Pandemi COVID-19 Terhadap Perekonomian Indonesia', Jurnal Benefita, 2020 <https://doi.org/10.22216/jbe.v5i2.5313>.

${ }^{8}$ Matdio Siahaan, 'Dampak Pandemi Covid-19 Terhadap Dunia Pendidikan', Jurnal Kajian Ilmiah, 2020 <https://doi.org/10.31599/jki.v1i1.265>.

${ }^{9}$ Ferdy Kusno, 'Krisis Politik Ekonomi Global Dampak Pandemi Covid-19', Anterior Jurnal, 2020.
} 
PROGRAM SMK (SAYA MURID KRISTUS) SEBAGAI PENDEKATAN ... (Yahya Fajar Edhi Nugroho, dkk)

"Dalam hal menguatkan iman orang percaya yang baru lahir baru dalam Kristus, maka sangat diperlukan adanya pemuridan yang dilakukan secara sistematis, berjenjang level iman, terstruktur dan kontinyuitas/berkelanjutan." ${ }^{10}$ Timbul masalah baru, yaitu bagaimana caranya melaksanakan Tugas amanat agung Kristus melalui peran gereja dalam bidang pemuridan kepada jiwa-jiwa baru tersebut di masa pandemi Covid-19? Sedangkan pelaksanaan Amanat Agung pemuridan yang selama ini dilakukan oleh gereja hanya dibatasi oleh ruangan/tempat yang terbatas dengan pertemuan langsung tatap muka secara onsite dan dengan waktu yang terbatas yang biasanya dilakukan di gedung gereja. Oleh sebab itu peneliti mencoba bagaimana agar Amanat Agung Kristus bisa tetap berjalan di masa pandemi ini melalui peran gereja khususnya dalam bidang pemuridan.

Melalui tulisan ini penulis memiliki tujuan mengajak para pembaca orang Kristen/gereja untuk terus melaksanakan tugas Amanat Agung Kristus dengan semangat dalam bidang pemuridan di masa pandemi dan dalam masa tantangan apa pun juga seperti yang sudah dilakukan oleh GBI Bethel Bandung yang ada dalam tulisan ini melalui program pemuridannya dengan melampirkan foto aktivitas kegiatan pemuridan selama mas pandemi Covid-19. Tulisan ini juga pasti akan memberikan manfaat kepada para pembaca terutama para mentor/fasilitator/gereja lainnya yang memiliki panggilan melayani di bidang penjangkauan jiwa dan pemuridan, supaya terus termotivasi untuk melakukan penjangkauan dan pemuridan jiwa-jiwa baru sesuai Amanat Agung Kristus dalam situasi apa pun juga.

\section{METODE PELAKSANAAN}

Ini karena suatu pelaksanaan yang terjadi dalam suatu pelayanan di gereja, maka diubah menjadi "Metode Pelaksanaan." ${ }^{11}$ Disampaikan metode penelitian bahwa menggunakan metode penelitian kualitatif: mengumpulkan semua buku-buku, ${ }^{12}$ Alkitab dan jurnal-jurnal yang berkaitan dengan penelitian yang memungkinkan menjawab masalah pelaksanaannya. Disampaikan pula pelaksanaan pemuridan yang selama ini dilakukan dan apa yang memungkinkan akan dilakukan pada masa pandemi Covid-19 ini.

Kegiatan pengabdian kepada masyarakat dilaksanakan oleh gereja GBI Bethel Bandung khususnya bagi masyarakat gerejawi/jemaat Kristen. Pelaksanakan kegiatan pengabdian kepada masyarakat ini disebut dengan program Saya Murid Kristus (SMK) dalam satu periode tiga bulan (Juni - Agustus 2020), pelaksanaannya setiap hari Minggu pukul 10.00 - 12.00 WIB, selama dua belas sesi kelas pemuridan sesuai dengan modul pengajaran pemuridan Saya Murid Kristus (SMK) berakar, tempat di rumah masing-masing selama masa pandem, menggunakan media online melalui zoom meeting, pengajaran pemuridan diberikan oleh team pastoral GBI Bethel Bandung dan ada sesi diskusi antara peserta/mentee dengan pembimbing/mentor, serta ada tugas harian yang harus diisi untuk menuntun pertumbuhan rohani para mentee/peserta. Peserta SMK dibatasi maksimal seratus peserta, dibagi kelompok sesuai batasan usia, peserta disebut sebagai mentee dan pembimbing disebut sebagai mentor/fasilitator, target pemuridan ini sampai peserta memahami bagaimana menjadi murid Kristus yang dewasa imannya sesuai prinsip alkitabiah dan dibaptis bagi peserta yang belum dibaptis.

\footnotetext{
${ }^{10}$ Patrecia Hutagalung, 'Pemuridan Sebagai Mandat Misi Menurut Matius 28:18-20', Pengarah: Jurnal Teologi Kristen, $2020<$ https://doi.org/10.36270/pengarah.v2i1.22>.

${ }^{11}$ Candy Happy Najoan, Jermias Tjakra, and Pingkan A K Pratasis, 'Analisis Metode Pelaksanaan Plat Precast Dengan Plat Konvensional Ditinjau Dari Waktu Dan Biaya (Studi Kasus : Markas Komando Daerah Militer Manado)', Jurnal Sipil Statik, 2016.

${ }^{12}$ Suwardi Endrasawara, Filsafat Ilmu (Edisi Revisi) (Yogyakarta: CAPS, 2015), p. 214.
} 


\section{PEMBAHASAN DAN HASIL}

\section{Amanat Agung Kristus}

Amanat Agung itu sangat penting, bukan saja karena merupakan misi utama semua gereja, tetapi juga karena faktanya gereja-gereja lokal baru bisa terbentuk apabila ada orangorang yang taat melaksanakan Amanat Agung Kristus. Tanpa pelaksanaan Amanat Agung tidak akan ada gereja-gereja lokal baru. Pelaksanaan Amanat Agung oleh gereja yang misioner menghasilkan gereja-gereja lokal. Orang percaya yang tergugah untuk memenuhi Amanat Agung Kristus, maka orang Kristen harus menjadi gereja yang menjangkau jiwa/misioner.

Gereja yang misioner adalah gereja yang setia melaksanakan misi menjangkau jiwajiwa baru. "Kata "misi" aslinya berasal dari kata Latin "missio" yang diangkat dari kata "mittere" merupakan terjemahan dari kata bahasa Yunani "apostello" yang artinya mengirim atau mengutus." ${ }^{13}$ Secara umum kata misi ini bisa merujuk untuk pengutusan seseorang dengan tujuan khusus, misalnya misi budaya dan kesenian." Dalam kekristenan, misi dipahami dalam arti pengiriman atau pengutusan gereja/jemaat ke dalam dunia, khususnya melalui sekelompok orang yang disebut misionaris untuk menjangkau orang-orang berdosa untuk percaya kepada Kristus sebagai Tuhan dan Juruselamat.” Dalam perkembangannya, misi memiliki makna yang cukup luas, yaitu: pengiriman atau penugasan misionari ke daerah tertentu; aktivitas yang dijalankan para misionari; wilayah geografis misonaris bekerja; lembaga yang mengirim misionaris; ladang misi atau lapangan misi yaitu dunia non Kristen; pusat pengutusan misionaris; dan rangkaian tugas pelayanan secara khusus menyebarkan Injil Kerajaan Allah dan pendirian jemaat baru. Jadi gereja yang misioner adalah gereja yang melakukan Amanat Agung Kristus. "Melaksanakan Amanat Agung adalah misi Kristus untuk gereja. Tujuan utama gereja memenuhi Amanat Agung. Amanat Agung Kristus adalah misi gereja yang merupakan kesinambungan dari misi Kristus Yesus." ${ }^{4}$ Dalam Matius 28:18-20, Tuhan Yesus memberikan tugas kepada murid-murid-Nya untuk pergi dan menjadikan semua bangsa murid-Nya dan membaptis dalam nama Bapa dan Anak dan Roh Kudus, dan mengajar melakukan segala sesuatu yang telah Tuhan perintahkan. Jadi melaksanakan Amanat Agung adalah tugas utama gereja/orang percaya dan merupakan kesinambungan misi Tuhan Yesus menyelamatkan umat manusia yang berdosa.

Firman-Nya dalam Injil Markus 16:15-20, Yesus berkata kepada muridnya untuk pergi ke seluruh dunia, beritakanlah Injil kepada segala makhluk. Siapa yang percaya dan dibaptis akan diselamatkan, tetapi siapa yang tidak percaya akan dihukum. Para murid pun pergilah memberitakan Injil ke segala penjuru dunia dan Tuhan turut bekerja dan meneguhkan firman itu dengan tanda-tanda yang menyertainya. Pengutusan murid-murid untuk menjadi saksi Kristus dan jaminan tanda-tanda mujizat yang menyertai selama menjadi saksi adalah perintah Tuhan Yesus yang harus ditaati dan dilaksanakan.

Tuhan ingin agar orang Kristen menjadi murid sejati dari Yesus Kritus yang bertumbuh dewasa secara rohani dalam pengenalan akan Allah, mengalami transformasi perubahan karakter dan sikap hidup dalam hidup kesehariannya. 15 "Pertumbuhan rohani ini akan dialami umat percaya jika mengetahui dan melakukan firman-Nya dalam kehidupan sehari-hari." ${ }^{16}$ Yesus Kristus memberikan perintah kepada murid-muridnya, inilah Amanat

\footnotetext{
${ }^{13}$ T. Gunawan Samuel, 'Melaksanakan Amanat Agung Kristus', Artikel.Sabda.Org (Palangka Raya, 2013).

${ }^{14}$ Herdiana, 'Pemuridan Kontekstual Bersdasakan Konteks Amanat Agung Kepada Pemuda Kristen Dalam Penelusuran Matius 28:16-20 Dan Implikasi Teologis. DU', Journal of Chemical Information and Modeling, 2013.

${ }^{15}$ Tony Salurante, 'Berteologi Global Dan Bermisi Dalam Konteks: Sebuah Usulan Kontekstualisasi Kekristenan Masa Kini', Ephigraphe, 4.2 (2020), p. 230.

${ }^{16}$ Rubin Adi Abraham, Saya Murid Kristus Modul Bertumbuh, ed. by Joko Prihanto, V (Bandung: Blessing Media, 2006), p. 5 .
} 
PROGRAM SMK (SAYA MURID KRISTUS) SEBAGAI PENDEKATAN ... (Yahya Fajar Edhi Nugroho, dkk)

atau Perintah Agung yang sangat penting bukan sekedar ayat agung, yang terus berlaku (kontinuitas) sampai akhir zaman. Jadi gereja yang misioner adalah gereja yang mengemban dan melaksanakan Amanat Agung Tuhan Yesus Kristus dan selain menginjil/memenangkan jiwa orang yang belum percaya, juga menekankan pemuridan/pengajaran nilai-nilai kebenaran alkitabiah akan pentingnya "menjadikan semua bangsa murid Kristus."

\section{Pemuridan Kristen}

"Seorang murid secara definisi adalah pengikut, seorang yang menerima/mendapat dan membantu menyebarkan/mewartakan doktrin. Seorang murid Kristen adalah orang yang menerima dan menyebarkan/mewartakan kabar baik tentang Yesus Kristus." Pemuridan Kristen yang didasari oleh Amanat Agung Kristus adalah proses dimana para murid berakar, bertumbuh dan berbuah di dalam Tuhan Yesus Kristus ${ }^{17}$ dan diperlengkapi oleh Roh Kudus, yang mendiami hati orang percaya, dalam mengatasi berbagai tekanan dan tantangan kehidupan ini dan semakin menyerupai Kristus.

Dalam tugas pemuridan, gereja sebagai suatu institusi komunitas iman melakukan tindakan pergi untuk mewartakan/menyampaikan Injil kabar baik sehingga setiap bangsa dapat menjadi bagian dari komunitas iman pada Yesus Kristus. Setiap orang yang masuk dalam komunitas iman pada Kristus, diterima dengan tanpa membedakan mereka, sebab tugas ini adalah tugas yang multikultural. "Pengajaran merupakan bagian penting dalam tugas pemuridan. Pemuridan dilakukan agar dapat memantapkan orang-orang yang baru percaya atau murid-murid baru masuk ke dalam komunitas iman pada Yesus, kemudian mereka menjadi murid Tuhan Yesus yang dapat diutus/ditugaskan untuk memuridkan orang lain."18 Proses pemuridan ini mengharapkan supaya orang percaya bisa meresponi dorongan Roh Kudus untuk menganalisa pikiran mereka, ucapan/perkataan dan tindakan/tingkah laku mereka dan membandingkannya dengan firman Allah. Orang percaya haruskan mempelajari firman di dalam Alkitab setiap hari, mendoakannya dan menaati melakukannya. Orang Kristen harus siap sewaktu-waktu untuk bersaksi akan pengharapan yang dimiliki di dalam Kristus (1Ptr. 3:15), juga tidak mudah diombang-ambingkan pengajaran sesat yang sedang ditawarkan oleh dunia dengan menguji segala sesuatu dari firman yang diterima (1Tes. 5:21) dan harus siap memuridkan jiwa baru untuk hidup berjalan dengan Tuhan Yesus.

Menurut Alkitab, menjadi murid Kristus melibatkan perkembangan kerohanian pribadi dari beberapa faktor melalui pengamatan berikut ini: (a) mengutamakan Kristus dalam segala sesuatu (Mrk. 8:34-38). Hidup memisahkan diri dari hawa nafsu dunia adalah ciri murid Kristus. Fokus hidupnya pada Kristus dan menyenangkan-Nya dalam setiap aspek kehidupan. Orang percaya harus menanggalkan ke-egoisan dan mengenakan pengutamaan Kristus; (b) menaati ajaran Tuhan Yesus (Yoh. 8:31-32). Orang percaya harus menjadi anak Tuhan yang melakukan firman. Ketaatan bagi orang percaya adalah ujian utama akan iman pada Allah (1 Sam. 28:18), dan Kristus merupakan teladan sempurna akan ketaatan-Nya dalam hidup-Nya di dunia dalam ketaatan tidak berdosa sempurna terhadap Bapa sampai mati (Fil. 2:6-8); (c) berbuah (Yoh. 15:5-8). Tugas orang Kristen menghasilkan buah. Dengan hidup berdiam melekat di dalam Kristus, dan melakukan firman-Nya, maka Roh Kudus akan menghasilkan buah, dan buah ini adalah hasil dari ketaatan orang percaya; (d) mengasihi murid yang lain (Yoh. 13:34-35); (e) penginjilan dan pemuridan jiwa petobat baru (Mat. 28:18-20). Sebagai orang percaya harus membagikan iman Kristen dan memberitahu kepada orang yang belum percaya akan perubahan yang luar biasa yang Yesus lakukan di

\footnotetext{
${ }^{17}$ Roedy Silitonga, 'Amanat Agung Dan Kemajemukan Beragam: Suatu Refleksi', STULOS, 2018.

${ }^{18}$ I Putu Ayub Darmawan, 'Jadikanlah Murid: Tugas Pemuridan Gereja Menurut Matius 28:18-20', Evangelikal: Jurnal Teologi Injili Dan Pembinaan Warga Jemaat, 2019 <https://doi.org/10.46445/ejti.v3i2.138>.
} 
dalam kehidupan percaya, serta menolong orang percaya baru untuk dimuridkan mengikuti teladan Kristus.

"Metode pemuridan umat Kristen saat ini sedang marak dibicarakan dan dilaksanakan oleh gereja-gereja di seluruh Indonesia." ${ }^{19}$ Gereja yang berkembang telah merasakan dampak dari hasil proses pemuridan dan pengajaran jemaatnya. Manfaat yang dapat dilihat dari pemuridan adalah bahwa seseorang yang telah mengikuti proses pemuridan mengalami pertumbuhan dalam kehidupan rohaninya, mulai dari berakar dalam Kristus menuju kepada kedewasaan seperti Kristus. Kedewasaan rohani sangat dibutuhkan oleh orang Kristen agar kehidupan mereka sungguh menggambarkan karakter Kristus lewat buah-buah kehidupan/tingkah laku yang bisa dirasakan oleh masyarakat di lingkungan sekitarnya. Orang percaya yang dewasa rohani akan memiliki iman yang kokoh dalam situasi hidup apapun juga. Gereja saat ini terus melakukan program pemuridan dalam segala situasi apa pun juga, bahkan gereja tidak hanya mengacu satu metode pemuridan harus onsite/pertemuan tatap muka saja. Gereja disituasi pandemi Covid-19 ini bisa terus melaksanakan Amanat Agung Kristus dalam bidang pemuridan/pengajaran nilai-nilai Alkitabiah kepada jemaatnya dan jiwa-jiwa baru secara online memanfaatkan kecanggihan teknologi dalam jaringan (daring) menggunakan google meeting atau zoom meeting.

\section{Pelaksanaan Pemuridan Saat Pandemi di Gereja Bethel Indonesia Bandung}

Pada 11 Maret 2020 lalu, World Health Organization (WHO) sudah mengumumkan status pandemi global untuk penyakit virus corona 2019 atau yang juga disebut corona virus disease 2019 (COVID-19). "Pandemi dalam hal kesehatan, berarti terjadinya wabah suatu penyakit yang menyerang banyak korban jiwa, serempak di seluruh penjuru dunia dan berbagai negara. Badan kesehatan dunia WHO menetapkan penyakit Covid-19 ini sebagai pandemi karena seluruh warga dunia berpotensi terkena infeksi penyakit COVID-19."20 "Dengan ditetapkannya status global pandemic tersebut, WHO menetapkan bahwa wabah COVID-19 merupakan darurat dunia internasional." ${ }^{21}$ Istilah pandemi Covid-19 menjadi suatu istilah yang sudah biasa dibicarakan oleh masyarakat umum sejak wabah Covid-19 mengalami penyebaran ke seluruh dunia pada masa sekarang ini, bahkan masyarakat dunia menyebut masa sekarang ini sebagai masa pandemi Covid-19.

Pada umumnya pelaksanaan Amanat Agung pemuridan yang selama ini dilaksanakan di gereja Tuhan dengan beberapa peserta yang dibatasi jumlah peserta dengan mempertimbangkan beberapa hal: ruangan/tempat yang terbatas, dengan pertemuan langsung tatap muka secara onsite dan dengan periode waktu yang terbatas yang biasanya dilakukan di gedung gereja. Kondisi pandemi Covid-19 ini membuat segalanya berubah, gereja harus mematuhi protokol kesehatan dari pemerintah: tidak boleh mengadakan pertemuan orang secara berkerumun, menjaga jarak, harus memakai masker, mencuci tangan dan mensterilisasi ruangan dengan disinfektan dan sinar lampu ultra violet untuk membunuh virus di ruangan. Namun hal ini tidak menyurutkan semangat gereja GBI Bethel Bandung untuk melaksanakan tugas Amanat Agung Kristus untuk memuridkan jiwa-jiwa baru yang percaya Kristus sebagai Tuhan dan Juruselamat.

Gereja GBI Bethel Bandung memanfaatkan kemajuan teknologi saat ini untuk melakukan pemuridan Kristen melalui pemuridan/pengajaran firman Tuhan secara daring/online menggunakan media zoom meeting. Untuk sesi sharing/diskusi kelompok serta mentoringnya menggunakan media online zoom meeting dan whatsapp. Dalam melaksanakan Amanat Agung Kristus GBI Bethel Bandung terus mengupayakan supaya lima tugas gereja bisa dilaksanakan kepada jemaatnya, yaitu: penyembahan (Yoh. 4:23-24);

\footnotetext{
${ }^{19}$ Agung Gunawan, 'Pemuridan Dan Kedewasaan Rohani', Jurnal Theologia Aletheia, 2017.

${ }^{20}$ Allianz Indonesia, 'Pandemi Pada Covid-19', Allianz.Co.Id (Jakarta, 2020).

${ }^{21}$ Ibid.
} 
PROGRAM SMK (SAYA MURID KRISTUS) SEBAGAI PENDEKATAN ... (Yahya Fajar Edhi Nugroho, dkk)

pelayanan (Mat. 25:31-46); penginjilan (Luk. 19:10); persekutuan (Ibr. 10:24-25; pengajaran (Ef. 4:12-16).

Pemuridan dalam gereja GBI Bethel Bandung dinamakan dengan program Saya Murid Kristus (SMK), dibagi dalam empat kelas level yang berbeda, yaitu: kesatu level berakar, pada level ini gereja mengajak komitmen jemaat baru untuk bertobat dan menerima Yesus sebagai Tuhan dan Juruselamat secara pribadi dalam hidupnya masingmasing, sampai mengambil komitmen pribadi untuk dibaptis dan tertanam dalam gereja lokal; kedua, level SMK bertumbuh, di level bertumbuh GBI Bethel Bandung sangat mengharapkan kaderisasi pelayan-pelayan Tuhan baru; ketiga, level berbuah, pada level berbuah ini pelayan-pelayan Tuhan akan disadarkan akan talenta/karunia dan potensi para pelayanan masing-masing, sehingga pelayanan yang tepat akan menghasilkan dampak yang maksimal dan luar biasa bagi pelebaran Kerajaan Allah di muka bumi ini; (d) level berbuah tetap, mencetak para leader baru untuk perintisan membuka gereja baru. Jadi intinya pada situasi apa pun juga, gereja GBI Bethel Bandung terus agresif melaksanakan Amanat Agung Kristus untuk menjangkau dan memuridkan jiwa-jiwa baru bagi Kristus.

Berikut ini adalah gambar foto dokumentasi pelaksanaan pengajaran kelas pemuridan gereja GBI Bethel Bandung Saya Murid Kristus (SMK) berakar pada masa Pandemi (Juni - Agustus 2020). SMK diikuti oleh tujuh puluh jemaat/mentee dan dua belas mentor/fasilitator, melalui media online zoom meeting setiap Minggu pukul $10.00-12.00$ WIB dan melalui SMK berakar ini menghasilkan dua puluh jemaat menyerahkan diri secara sukarela untuk dibaptis menerima Tuhan Yesus sebagai Tuhan dan Juruselamat serta komitmen untuk hidup lahir baru.

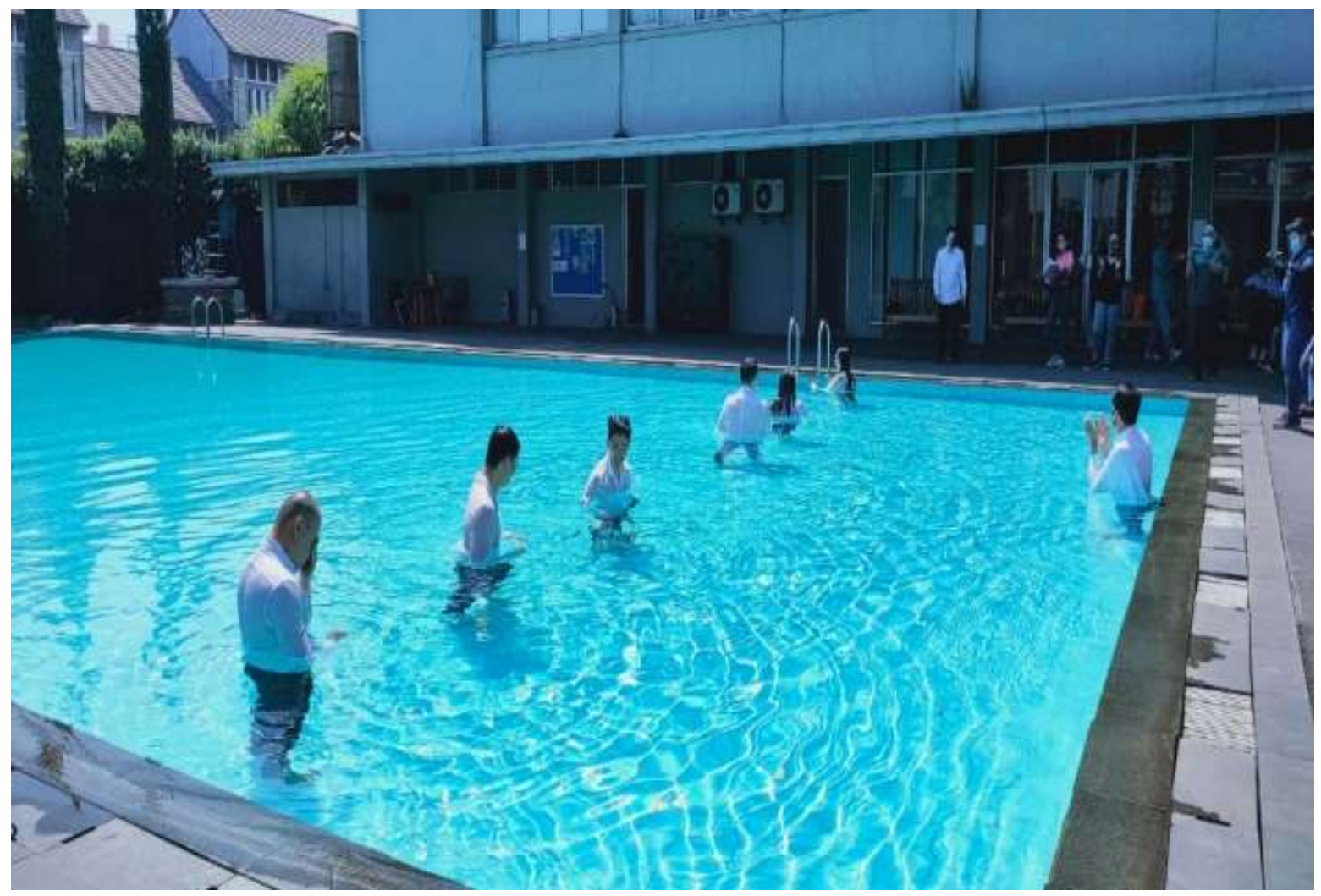

(Gambar 1. Baptisan Air Peserta Pemuridan SMK Berakar GBI Bethel Bandung) 


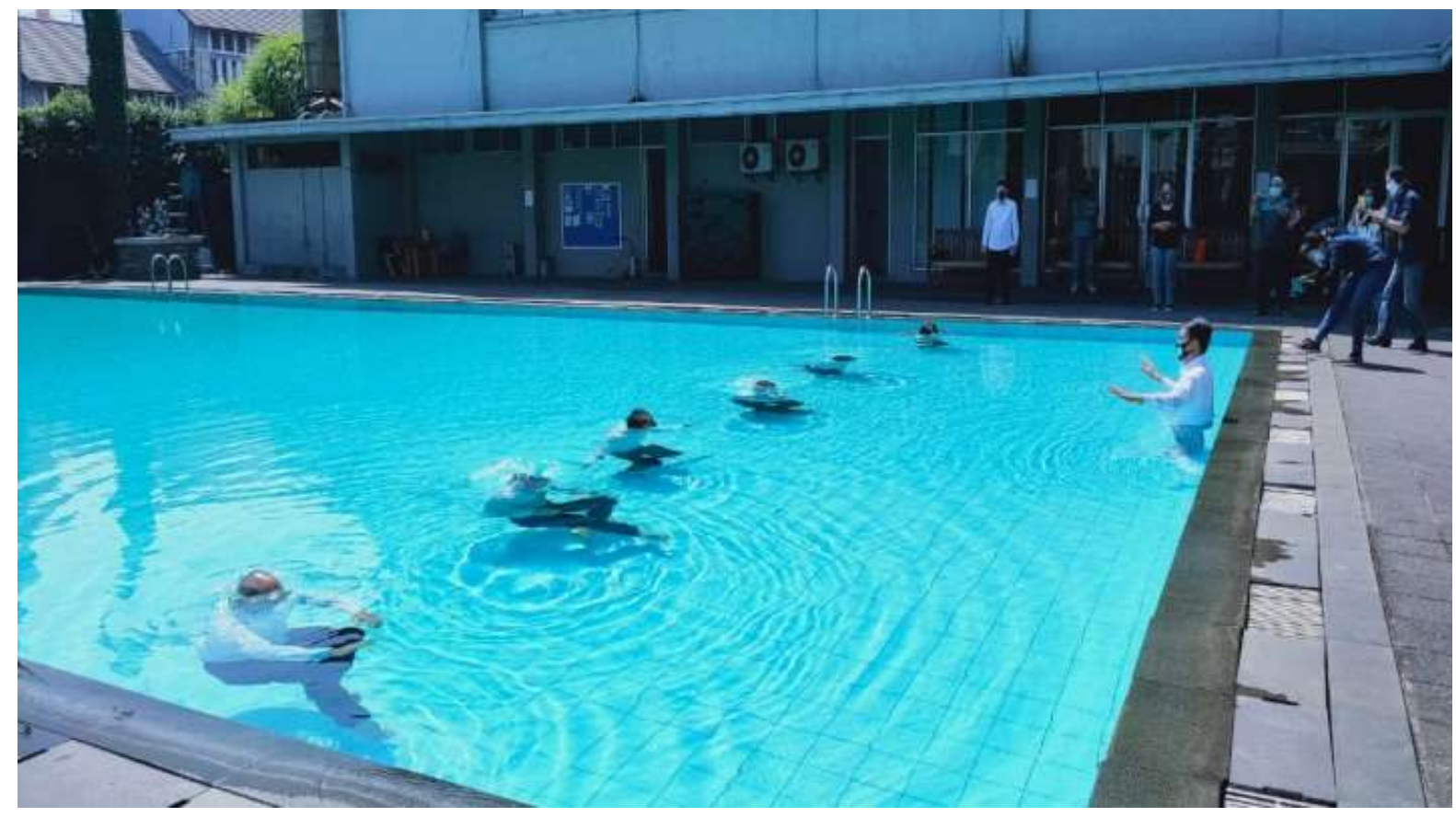

(Gambar 2. Baptisan Air Peserta Pemuridan SMK Berakar GBI Bethel Bandung)

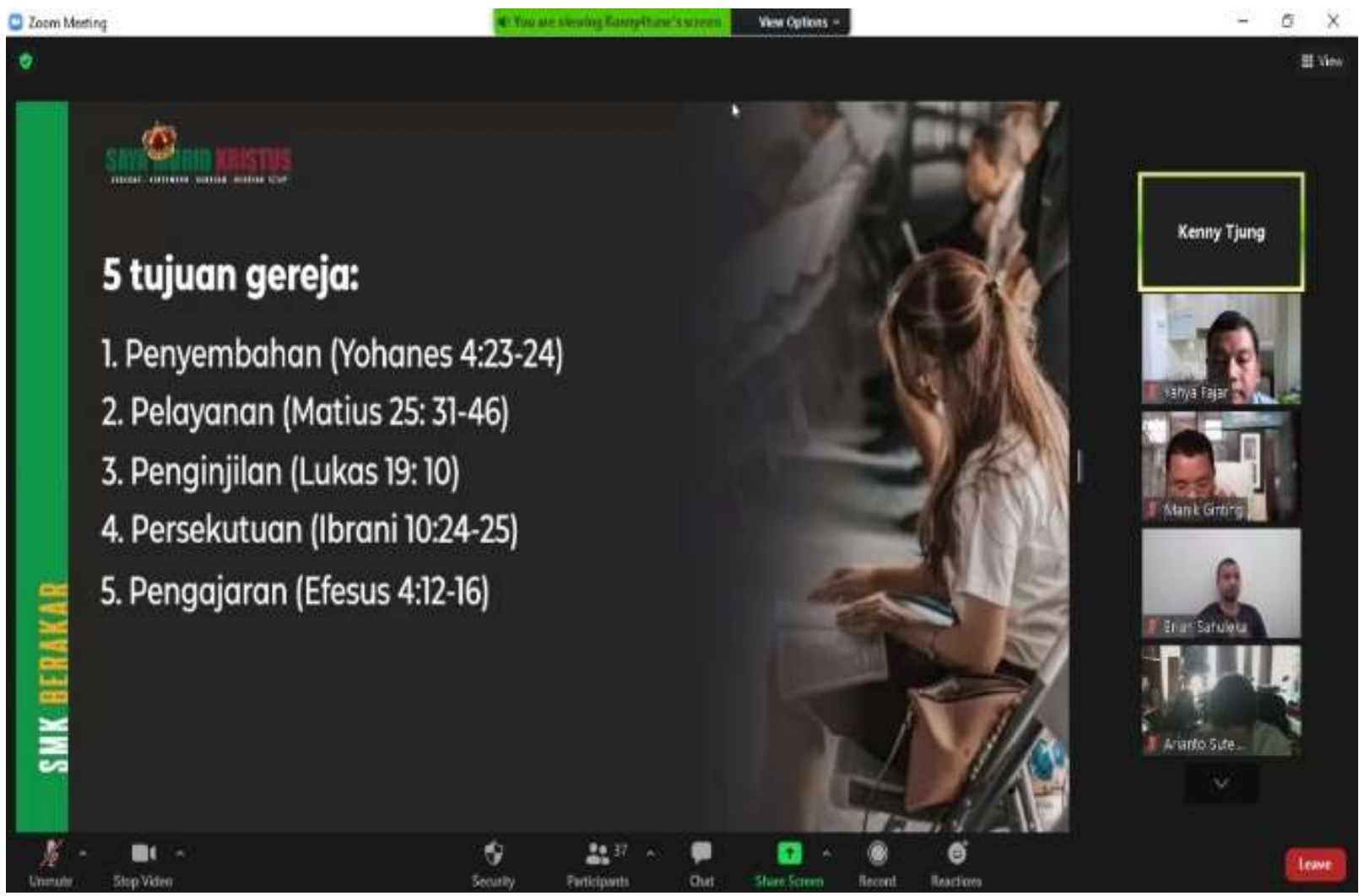

(Gambar 3. Sesi Pengajaran Firman Tuhan Pemuridan SMK Berakar GBI Bethel Bandung) 
PROGRAM SMK (SAYA MURID KRISTUS) SEBAGAI PENDEKATAN ... (Yahya Fajar Edhi Nugroho, dkk)

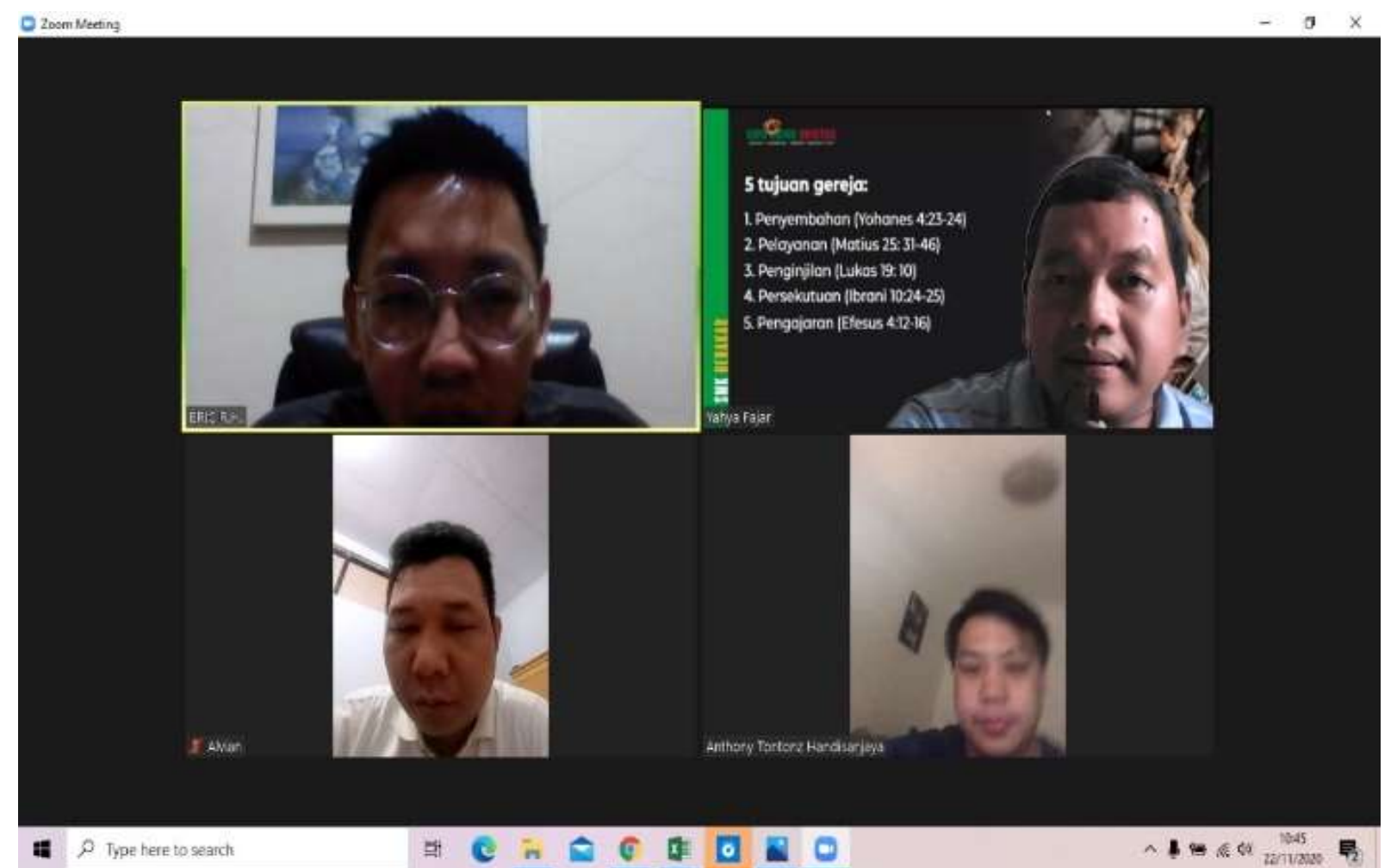

(Gambar 4. Sesi Diskusi Kelompok Mentee dan Mentor SMK Berakar GBI Bethel Bandung)

"Dalam pemuridan setiap peserta bukan hanya menjadi pendengar khotbah/pengajaran, melainkan akan didampingi oleh seorang pembimbing (fasilitator atau mentor) yang akan memimpin sharing kelompok dan juga menjadi pembina." Tujuannya agar peserta mengalami kebenaran firman, mengalami perjumpaan dan pemulihan dengan Tuhan sendiri, juga mengalami kuasa dan kasih Kristus. Jadi dalam situasi apa pun juga Tuhan pasti membuka jalan kepada umat-Nya yang dengan rela hati dan sungguh-sungguh mau melayani jiwa-jiwa baru yang percaya dalam bidang pemuridan/pengajaran baik secara onsite/pertemuan langsung maupun secara online/daring dengan menggunakan media zoom meeting atau whatsapp, sebab pemuridan/pengajaran inilah bagian dari Amanat Agung Kristus bagi orang percaya.

\section{KESIMPULAN}

Dampak positif yang bisa dirasakan dengan adanya pandemi ini membuat pelaksanaan tugas pemuridan bisa dilakukan tanpa batasan tempat, ruang dan waktu. Pengajaran dan pemuridan di masa pandemi Covid-19 ini bisa dilaksanakan lewat kelas pemuridan secara online/zoom meeting dan mentoringnya pun dapat dilakukan secara harian, baik secara pribadi antara mentor dengan menteenya maupun lewat grup mentoring dengan menggunakan WhatsApp dan telepon, sehingga pesertanya pun bisa diikuti oleh peserta yang berdomisili/tinggal di kota lain bahkan negara lainnya juga.

Dalam melaksanakan Amanat Agung tidak berhenti hanya sebatas sampai memenangkan jiwa baru melalui penginjilan. Pelaksanaan Amanat Agung harus dilakukan secara tuntas dengan pemuridan dan pengajaran firman Tuhan yang komprehensif/secara lengkap sistematis, serta bimbingan jiwa baru sampai ke tahap dewasa iman. Setelah dewasa iman orang percaya yang telah dimuridkan, maka orang percaya tersebut harus siap untuk diutus memenangkan jiwa dan memuridkan orang yang belum percaya Kristus lainnya. 
Penelitian ini bisa berkontribusi menyadarkan dan mendorong/mengajak pembaca Kristen/gereja untuk tidak berhenti hanya sebatas menjadi orang Kristen saja, melainkan menjadi jemaat Kristus memiliki kesadaran untuk memenangkan jiwa-jiwa yang berdosa menjadi orang yang percaya Kristus dan memuridkan jiwa-jiwa yang sudah percaya sampai mencapai kedewasaan rohani, dan mengutusnya untuk menjadi penjangkau jiwa-jiwa baru lainnya untuk diselamatkan.

\section{DAFTAR PUSTAKA}

Abraham, Rubin Adi, Saya Murid Kristus Modul Bertumbuh, ed. by Joko Prihanto, V (Bandung: Blessing Media, 2006)

Alinurdin, David, 'COVID-19 Dan Tumit Achilles Iman Kristen', Veritas: Jurnal Teologi Dan Pelayanan, $2020<$ https://doi.org/10.36421/veritas.v19i1.373>

Darmawan, I Putu Ayub, 'Jadikanlah Murid: Tugas Pemuridan Gereja Menurut Matius 28:18-20', Evangelikal: Jurnal Teologi Injili Dan Pembinaan Warga Jemaat, 2019 <https://doi.org/10.46445/ejti.v3i2.138>

Faiza, Mutia, 'Dampak Corona, Jumlah Pengangguran Bisa Tembus 12,7 Juta Di 2021', Kompas.Com (Jakarta, 2020)

Gunawan, Agung, 'Pemuridan Dan Kedewasaan Rohani', Jurnal Theologia Aletheia, 2017

Herdiana, 'Pemuridan Kontekstual Bersdasakan Konteks Amanat Agung Kepada Pemuda Kristen Dalam Penelusuran Matius 28:16-20 Dan Implikasi Teologis. DU', Journal of Chemical Information and Modeling, 2013

Hutagalung, Patrecia, 'Pemuridan Sebagai Mandat Misi Menurut Matius 28:18-20', Pengarah: Jurnal Teologi Kristen, 2020 <https://doi.org/10.36270/pengarah.v2i1.22> Indonesia, Allianz, 'Pandemi Pada Covid-19', Allianz.Co.Id (Jakarta, 2020)

Kusno, Ferdy, 'Krisis Politik Ekonomi Global Dampak Pandemi Covid-19', Anterior Jurnal, 2020

Najoan, Candy Happy, Jermias Tjakra, and Pingkan A K Pratasis, 'Analisis Metode Pelaksanaan Plat Precast Dengan Plat Konvensional Ditinjau Dari Waktu Dan Biaya (Studi Kasus : Markas Komando Daerah Militer Manado)', Jurnal Sipil Statik, 2016 Nasution, Dito Aditia Darma, Erlina Erlina, and Iskandar Muda, 'Dampak Pandemi COVID19 Terhadap Perekonomian Indonesia', Jurnal Benefita, 2020 <https://doi.org/10.22216/jbe.v5i2.5313>

Question, Got, 'Apakah Pemuridan Kristen', Gotquestion.Org (Jakarta, 2020)

Reihan Sebayang, 'Singapura Resesi, Jerman Dan Jepang Juga', Cnbcindonesia (Jakarta, 2020)

Roedy Silitonga, 'Amanat Agun Dan Kemajemukan Beragam: Suatu Refleksi', STULOS, 2018

Salurante, Tony, 'Berteologi Global Dan Bermisi Dalam Konteks: Sebuah Usulan Kontekstualisasi Kekristenan Masa Kini', Ephigraphe, 4.2 (2020), 225-35

Samuel, T. Gunawan, 'Melaksanakan Amanat Agung Kristus', Artikel.Sabda.Org (Palangka Raya, 2013)

Siahaan, Matdio, 'Dampak Pandemi Covid-19 Terhadap Dunia Pendidikan', Jurnal Kajian Ilmiah, 2020 <https://doi.org/10.31599/jki.v1i1.265>

Suwardi Endrasawara, Filsafat Ilmu (Edisi Revisi) (Yogyakarta: CAPS, 2015) 